\title{
PREPARATION AND ANALYSIS OF PR-GA-AL ALLOYS
}

\author{
$\underline{\text { Ismailov M.Sh. }^{*}}{ }^{*}$ Yamshchikov L.F. ${ }^{1}$, Melchakov S.Yu. ${ }^{2}$ \\ ${ }^{1}$ Ural Federal University, Yekaterinburg, Russia \\ ${ }^{2}$ Institute of Metallurgy, Ural Branch of RAS, Yekaterinburg, Russia \\ *E-mail: murodzhon.ismailov@mail.ru
}

Pr-Ga-Al alloys were prepared from individual metals $\mathrm{Pr}, \mathrm{Ga}, \mathrm{Al}$ purified from oxide films in an inert atmosphere of the glove box. The metals were mixed in a certain proportion in crucibles and annealed at $832.4 \pm 1.7{ }^{\circ} \mathrm{C}$ and $366.2 \pm 6.3{ }^{\circ} \mathrm{C}$ for 19 hours and 53 hours respectively. Three ingots were obtained with different praseodymium content. X-ray phase analysis showed that the dominant phase of these alloys is $\operatorname{PrGa}_{6}$. A formation of $\operatorname{Pr}(\mathrm{GaAl})_{2}$ solid solution was also detected.

Praseodymium is one of the common rare earth elements. The phase diagrams of praseodymium alloys with p-elements are relatively well studied, although they require further researches. For example, the phase diagram of $\mathrm{Pr}-\mathrm{Ga}$ alloys is studied poorly in the field of praseodymium concentrations of 30-40 wt.\% [1,2].

The composition of the intermetallic compound $\mathrm{PrGa}_{4}$ on the Pr-Ga phase diagram is indicated tentatively. Moreover, its structure is not known yet. The ternary phase diagram of the Pr-Ga-Al system is also not defined in the open literature.

Since Pr is a component of spent nuclear fuel (SNF), therefore, the aim of our investigation is a comprehensive study of alloys of this metal with a liquid metallic GaAl melt promising for SNF reprocessing.

Samples of individual metals $\mathrm{Pr}, \mathrm{Ga}, \mathrm{Al}$ were previously cleaned from oxide films, degreased with alcohol and stored in an inert box. According to the Ga-Al phase diagram [1], the eutectic composition was fixed: $99.2 \mathrm{wt} \%$ of Ga (its melting point is 26.6 ${ }^{\circ} \mathrm{C}$ ). The concentration of praseodymium was chosen in accordance with the poorly studied field of the Pr-Ga phase diagram. Three alloys were prepared. The compositions of the alloys are presented below. Their composition was determined by chemical analysis using an AES-ICP spectrometer Optima 2100DV. The deviations of analysis were calculated according to the error accumulation law.
Alloy $\quad \mathrm{w}(\operatorname{Pr}), \%$
$\mathrm{w}(\mathrm{Ga}), \%$
$\mathrm{w}(\mathrm{Al}), \%$
$\# 1$
$76.43 \pm 2.43$
$0.63 \pm 0.02$
$\# 2$
$68.31 \pm 2.17$
$0.57 \pm 0.02$
\#3
$27.15 \pm 0.86$
$61.03 \pm 1.94$
$0.50 \pm 0.02$

During the experiment, all alloys annealed into crucibles inside the experimental cell were held at $832.4 \pm 1.7^{\circ} \mathrm{C}$ and $366.2 \pm 6.3^{\circ} \mathrm{C}$ for 19 hours and 53 hours, respectively. The temperatures of alloys were recorded periodically using the K-type thermocouple.

After the experiment, the cell was cooled, and the alloys were extracted. Three ingots of these alloys were obtained. The first ingot was powdery. Ingots \#2 and \#3 were fragile and very hard, they have not sawn with hands and these ingots were cleaved at the edges. Therefore, the cut was carried out with a diamond saw to look at the radial 
and longitudinal section of these alloys, as well as to prepare samples for X-ray phase analysis.

X-ray phase analysis showed that alloys \#2 and \#3 consisted only of a mixture of $\mathrm{PrGa}_{6}$ intermetallic compound and $\operatorname{Pr}(\mathrm{GaAl})_{2}$ solid solution (see figure 1). Moreover, the content of $\operatorname{Pr}(\mathrm{GaAl})_{2}$ compound in the alloy \#3 was more than in the second ingot.

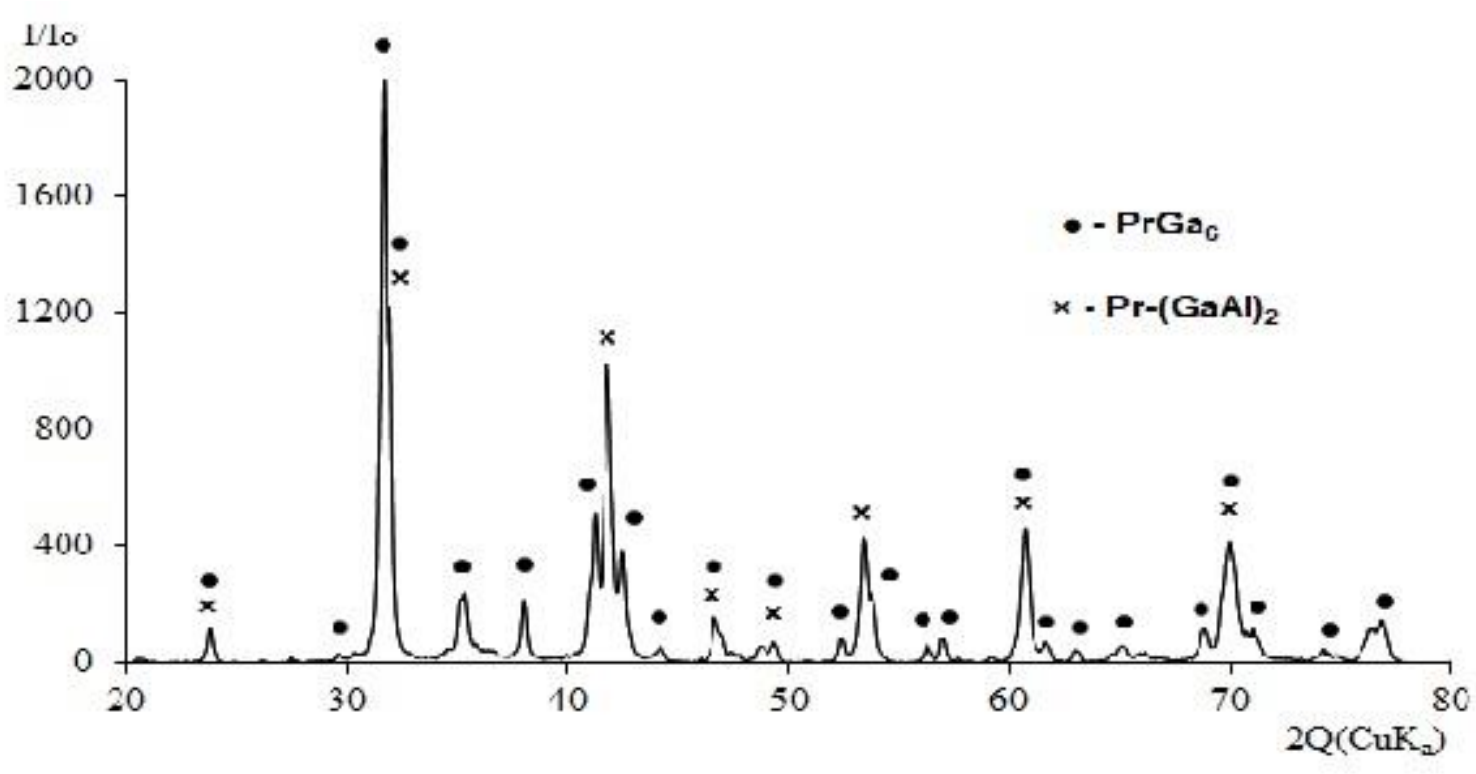

Fig. 1. XRD pattern of alloy \#3.

1. Baker H., Okamoto H. et al. ASM Handbook. Alloy Phase Diagrams vol. 3, ASM International (1992).

2. Lyakishev N.P. Diagrammy sostoyaniya dvoinykh metallicheskikh sistem, vol. 2, Mashinostroenie (1997). 